\title{
Shakespearean Girlhoods in Contemporary Australian Young Adult Fiction
}

\section{Erica Hateley}

\section{(2) OpenEdition \\ 1 Journals}

\section{Electronic version}

URL: http://journals.openedition.org/shakespeare/3381

DOI: 10.4000/shakespeare.3381

ISSN: 2271-6424

\section{Publisher}

Société Française Shakespeare

\section{Electronic reference}

Erica Hateley, «Shakespearean Girlhoods in Contemporary Australian Young Adult Fiction », Actes des congrès de la Société française Shakespeare [Online], 33 | 2015, Online since 10 October 2015,

connection on 03 June 2020. URL : http://journals.openedition.org/shakespeare/3381 ; DOI : https:// doi.org/10.4000/shakespeare.3381

This text was automatically generated on 3 June 2020 .

(c) SFS 


\title{
Shakespearean Girlhoods in Contemporary Australian Young Adult Fiction
}

\author{
Erica Hateley
}

A great find was an edition of Shakespeare. Well do I remember those two fat, weighty volumes, handsomely bound in calf, printed on the thickest and glossiest of paper, and copiously illustrated.

[...] When I first went to school, my ability to quote Shakespeare proved a source of embarrassment to myself and of ill-will among my companions. It wasn't considered "the thing" in a younger girl. Worse still for her to air her

knowledge. In time I grew wise and kept it to myself. ${ }^{1}$

So remembers Henry Handel Richardson (1870-1946) of her girlhood acquisition and subsequent peer-induced suppression of Shakespeare. This anecdote reveals the ambivalent status of Shakespeare in Australian culture, where his works are not only an artefact of British Imperialism and a marker of cultivated taste, but also marked by oppositional possibilities-of potential resistance to hierarchies of nation or culture, but less so of gender. Such ambivalence informs recent Australian young adult (YA) appropriations of Shakespeare for and about young women. In these novels, female protagonists make sense of themselves by making sense of Shakespeare, and in so doing claim subjectivity for themselves. However, even as Shakespearean cultural agency is made the purview of girlhood, gender norms continue to exert enormous pressure on what the most desirable subjectivity might be. Such novels thus address "the two key themes of girl studies [...] the (in)significance of girl culture and the problem of girls' agency", ${ }^{2}$ and do so in a context of ongoing (post)colonial and patriarchal anxiety. 
1 In Australian culture, as elsewhere, 'Shakespeare' is a discursive formation attracting veneration (of the 'greatest writer in the English language', or 'universal insights into humanity' type), aspiration (of the assertive 'Australians can do Shakespeare as well as anyone', or the more self-abnegating 'will the Imperial Mother be proud if we do Shakespeare well' variety), and far more rarely, of resistance ('we don't need Shakespeare'). When Shakespeare is taken up by (or for) Australians, there is an ongoing (post)colonial anxiety as well as the more broadly familiar high/pop culture tensions which have been the object of much scholarship and comment in recent decades. Wide-ranging cultural debates about the meaning, relevance, or authority of Shakespeare in Australia have particular relevance for adolescent Australians, not least because the debates frequently surface in public and pedagogical conversations about whether or how Shakespeare should be taught in Australian high schools. Classes of students are routinely taken (dragged?) to live performances of Shakespearean plays (which are themselves likely to be wrestling with the meaning and significance of 'Australian Shakespeare'), and regardless of what politically conservative panicmongers in the popular media would like people to believe, Shakespeare is taught in high-school English classrooms throughout the country. ${ }^{3}$

2 An often overlooked site of Shakespearean education for Australian adolescents-and perhaps especially Australian adolescent women-is that of young adult (YA) literature. As a genre, YA engages in socialising and acculturating functions for its implied readership, often rendering social and cultural values as normative via narrative strategies which link desirable subject positions, behaviours and outcomes with particular values, and via strategies of narration, which position readers to take up particular dispositions towards those narrative values. When YA is 'Shakespeared' it often presses the Shakespearean playtext or the more generally understood discursive cultural capital of Shakespeare into service as an authority for, or justification of, conservative narrative and social values.

3 When Shakespeare is taken up by YA literature, it produces a mode of acculturation and socialisation wherein the Shakespearean is to be intrinsically valued and is often simultaneously used to value other social or cultural concepts. As with many theatrical productions then, YA appropriations of Shakespeare both mediate and interpret Shakespearean content for their audience. In the Australian context, YA novels both reflect and shape the pedagogical and cultural debates about Shakespeare, often expressing a desire for what has been described in theatrical terms as "the authentication of self-evidently and unambiguously alien texts as national cultural products". ${ }^{4}$ Even if "in the last years of the twentieth century the plays were beginning to be accepted again as entertainment rather than as more rarefied educational or aesthetic experiences. And that meant they were entering the national consciousness as genetically Australian, not imported, experiences", ${ }^{5}$ young Australians continue to be acculturated into particular dispositions towards Shakespeare as cultural authority non pareil.

4 Such dispositions are not only nationed but also gendered. The default discursive subject position in and of Australian culture is resolutely masculine. In Australia as elsewhere then, girlhood is always already freighted with the 'impediments' of youth and non-masculinity and distinguished from the quintessential Australian subject position. And, of course, while it falls beyond the scope of this discussion, an intersectional analysis reminds us of the many other variables of the normative-class, 
race, ethnicity, sexuality, religion, and so forth-which comprise the messy business of subjectivity and social agency in Australia and the wider world. Even in its most straightforward formulation, Marnina Gonick describes two dominant discourses of contemporary girlhood, "Girl Power" and "Reviving Ophelia" as offering "contradictory identificatory possibilities". ${ }^{6}$ It is not only since Mary Pipher's Reviving Ophelia appeared that the already tangled experience of girlhood has been bound up with Shakespeare. Susan J. Wolfson has traced contradictory identificatory possibilities in Romantic girls' reading of Shakespeare: “A book of Shakespeare in a girl's hands, though it may offer her models for her principal ends as woman, also allowed her a chance to read in temporary freedom from cultural supervision and its expectations of proper English womanhood". ${ }^{8}$ The competing experiences of liberation and constraint which mark girlhood in general are multiplied in Shakespearean girlhoods.

Within a decidedly neoliberal, heteronormative, patriarchal culture such as that of contemporary Australia, girls are "simultaneously recognized as the potential idealized autonomous neoliberal subject even as they are always already at risk of failing to secure the position", 9 and I would add, are seen as a risk to the existing culture if they do secure the position. Henry Handel Richardson's autobiographical memory reveals that the claiming of a colonial Shakespearean identity may well extend and complicate the Romantic ideology described by Susan J. Wolfson. So too may the expectations of contemporary girlhood-internalised and enforced no less by other girls than by sociocultural contexts-seek to repulse the Shakespearean, or to find ways of incorporating it into acceptable femininity, and thus neutralise its destabilising potential while retaining its cultural status.

6 YA appropriations of Shakespeare usually offer both an introduction to or interpretation of Shakespearean playtexts and an intratextual model for or message about how 'to be' a reader or consumer of the Shakespearean. Hypothetically then, they save their implied reader from Richardson's social humiliation by offering not only competence in Shakespeare, but also instruction on how to manage and perform (or not perform) that competence in public. This need not necessarily be a conservative or constraining function, but it often happens that YA fiction not only encodes limited and limiting models of adolescent femininity, but also offers highly selective examples from or perspectives on, the Shakespearean text. In linking the two, conservative girlhood and conservative Shakespeare are made mutually constituent. So, while I wish to emphasise 'girlhood' as a category of subjectivity which enables, may even be comprised of, potential and of becoming-ness, rather than as 'at-risk', dependent, or endangered, I am aware of the ways in which popular literary genres (such as the YA romance novel) may perpetuate the latter. Insidiously, they often do so under cover of seeming to endorse the former, and not infrequently, mobilise Shakespeare to authorise their sociocultural agendas.

7 A handful of contemporary Australian YA novels appropriate Shakespeare for girls by way of (largely realist) stories about young women navigating their social and school lives in ways at least partly informed by their encounters with Shakespeare. ${ }^{10}$ The YA romance novels I read here are all appropriations of Shakespeare insofar as they not only depict characters engaging with Shakespeare, but "contain instruction about how and/or why to read" Shakespeare. ${ }^{11}$ This socialising function aligns the novels politically with those Australian productions of Shakespeare which seek to render the plays as local, and pedagogically with school-based teaching of Shakespeare as 
'inherently relevant' to adolescents' lives, but takes neither for granted. Rather, such appropriations explore ways in which Shakespearean texts might be relevant to contemporary Australian adolescents. What can be seen at work in these novels, are the contradictions of 'Australian Shakespeare' and those of 'girlhood' brought into relief. The resulting narratives tend to address issues of schooling and of gender by connecting the Shakespearean with pedagogical subjectivities or with personal subjectivities, but rarely with both, and the codes of the romance genre often combine with the socialising function of YA, to offer specifically gendered models of Shakespearean subjectivity.

Charlotte Calder's Cupid Painted Blind ${ }^{12}$ uses A Midsummer Night's Dream as the basis for its plot and also depicts protagonist Persephone Harkness coming to a deeper understanding of herself and her interpersonal relationships through school-based engagement with the play. I have discussed Cupid Painted Blind more fully elsewhere, ${ }^{13}$ but I draw upon it here as a kind of exemplar narrative wherein 'girlness' trumps 'Australian-ness' in Shakespearean YA. Persephone is studying the play in school, and negotiating peer relationships within and beyond school settings. When assigned to perform a scene from A Midsummer Night's Dream, extra-curricular rehearsals mean that these two experiences converge. Persephone's happy ending is marked by romantic success and a renewed relationship with her estranged father.

The novel's focus on romance and sexuality at the expense of intellectual or professional development is hardly unique to Cupid Painted Blind-indeed, it could be said of much YA romance fiction aimed at young female readers. What makes it especially troublesome is the use of Shakespeare to authorise the split, and to suggest that young women must commit to one of two Shakespearean paths: the personal, emotional, romantic, desirable path which is walked outside the academy, or the academic, intellectual, professional, second-best path which leads through school.

There is, however, an interesting implication that schools themselves enforce this split: unwilling or unable to address issues of sexuality or romance within the Shakespearean text. While reading Dream for homework, Persephone contemplates the gap between the play's depiction of romantic attraction and her own understanding of it:

\footnotetext{
But then she wondered if Shakespeare meant them to be pashing, in between all the words. She remembered back to the year before, when Year 9 had been taken to see a schools performance of As You Like It, staged by a professional theatre company. The stage lovers had been all over one another. [...] And, of course, there was all that passion in the movie version of Romeo and Juliet...

Seph went over the lines again, imagining herself as the director. ${ }^{14}$
}

On the one hand, Seph's more personal and direct engagement with the play can be lauded, but on the other hand, the distinction of this engagement from school-based Shakespeare study enforces the 'two paths' mentioned above. In a YA romance novel, the protagonist and implied reader are each presumed to desire romantic closure. When that closure is made mutually exclusive with academic development, Shakespeare becomes an agent of closing down possibilities for the protagonist rather than opening them up. For the novel as a whole, Shakespeare is pressed into the service of reinforcing social norms rather than challenging them. To be clear, it is not the emphasis on personal relationships (with Shakespeare or with other people) that is 
troubling, but the severing of successful personal relationships from scholarly (professional) success.

11 By way of contrast, in J.C. Burke's Faking Sweet ${ }^{15}$ by studying Much Ado About Nothing in English at a new high school, protagonist Holly learns to navigate girl-girl relationships, develops a romance plot, and advances academically. Holly is an excellent student who loves English, but dislikes Shakespeare, ${ }^{16}$ until the English teacher at her new all-girls' school announces 'We're going to have a go at relating Shakespeare's Much Ado About Nothing to our own lives". ${ }^{17}$

The novel's depiction of reading Much Ado at least emphasises paced, thoughtful reading of the whole play over time. While this serves an obvious structural purpose for the novel, it also suggests that understanding of a play is unlikely to result from intense focus on just one scene or one character. Nonetheless, it trades on simplistic educational logics of literature influencing readers; that is, in wholesale behavioural ways, rather than more nuanced sociocultural or ideological senses.

Over the course of Faking Sweet, Much Ado is invoked as a play 'about' reputation, romantic confusion, and villainy. ${ }^{18}$ The novel's definition of girlhood may be inferred from its insistence that Much Ado is appropriate for an all-girls' school because the students are presumed to be spreading rumours, lying about each other, and generally in competition for social status. ${ }^{19}$ One pedagogical solution to these deficits is to use Much Ado as a kind of conduct book-cum-cautionary tale:

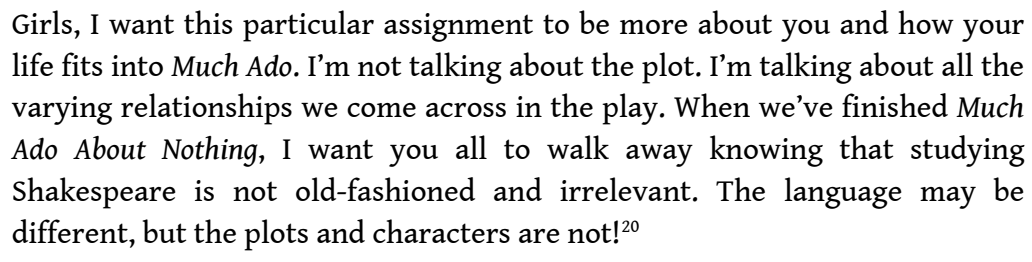
life fits into Much Ado. I'm not talking about the plot. I'm talking about all the varying relationships we come across in the play. When we've finished Much Ado About Nothing, I want you all to walk away knowing that studying Shakespeare is not old-fashioned and irrelevant. The language may be different, but the plots and characters are not! ${ }^{20}$

Even as the novel emphasises the relevance to the lives of contemporary girls, it suppresses the politics of gender and sexuality which in the play guarantee Hero's social death. This could be seen as a preference for the personal over the political rather than an engagement with the personal as political which characterises much feminist thinking and practice. Of course, this approach succeeds, and having extricated herself from a toxic girl-girl friendship and struck up a positive girl-girl friendship, Holly is rewarded with an ideal romantic relationship with the male cousin of her new BFF.

Faking Sweet points to the fact that in YA appropriations of Shakespeare, it is generally (albeit not always) the case that adolescent readers are invited to identify with, and value highly, the experience of reading Shakespeare. Indeed, it is often true that a protagonist's coming-of-age, personal development, and/or plot resolution rests on embracing the reading of Shakespeare. However, in several of the Australian YA texts discussed here, tensions between school and not-school Shakespearean experience are managed by focussing on the productively liminal site of school-based but extracurricular performances of Much Ado About Nothing, A Midsummer Night's Dream, and The Tempest.

16 Tara Eglington's How to Keep a Boy from Kissing You ${ }^{21}$ most fully fits stereotypes of romance fiction as a genre that perpetuates retrograde ideas about gender and social relations. Sixteen-year-old Aurora is extremely beautiful, popular, and has many 
potential suitors, but is waiting for an ideal partner to share her first kiss. When her high school mounts a production of Much Ado About Nothing, she is cast as Beatrice to her next-door neighbor Hayden's Benedick. Over the course of the novel, these two realise they are an ideal pair, despite years of bickering.

Knowing references to fairy tales and occasional gestures towards proto-feminist rhetoric-e.g. "It's about us girls valuing ourselves and saying no to guys who use or abuse us", ${ }^{22}$ or "I was all for my friends being independent women. But..." ${ }^{23}$-only throw into relief the stereotypical gender ideologies circulated by this novel. ${ }^{24}$ Such contradictions can be seen also in the Shakespearean elements. Aurora describes herself as hero-worshipping Shakespeare, ${ }^{25}$ claims that Harold Bloom "was a god", ${ }^{26}$ and aspires to be a writer (where her mother wants her to be a model). However, she needs to look Much Ado up on the Internet to get a sense of the play, and does not know how it ends even after she has been cast as Beatrice and rehearsals have commenced. ${ }^{27}$

Similarly, the production's director decides that because "the attitudes [to gender] in Shakespeare's time were obviously very different from our own", he has "decided to set it in the 1950s". ${ }^{28}$ The implied cultural myth is one in which the 1950s represents an apogee of straightforwardly patriarchal or "sexist" social organisation. By implication, the young women in the novel, and the implied readers of the novel, will accept the "very different from our own" as true. The novel itself, however, unproblematically reproduces the gender politics it ascribes to Much Ado, up to and including its finale: Aurora's first kiss which is designed by Hayden to take place on the school's theatrical stage, but without an audience. Shakespeare is most important in this novel for structuring and enabling a romance plot.

Elsbeth Edgar's In the Wings ${ }^{29}$ is more conscious of its engagement with girlhood as an experience of change and growth. Protagonist Ella is struggling to connect with girlfriends who only want to "talk about boys and clothes", ${ }^{30}$ while she is interested in fantasy stories and plays. Ultimately, the novel connects such fantasy with personal growth when a little 'Shakespearean magic' sees Ella move from working backstage to performing in her school's production of A Midsummer Night's Dream. As is often the case in appropriations of A Midsummer Night's Dream for young people, the play is effectively reduced to its fairy plot here. Not coincidentally, this facilitates a somewhat asexual romance plot: Ella forms a bond with the boy playing Puck, but their relationship never intersects with those of Shakespeare's young lovers (who surely offer a more obvious point of identification for contemporary adolescent readers).

In fact, Ella becomes the figure through and around whom male characters cement social bonds, affirm their shared Shakespearean and theatrical knowledge, and shape Ella's growth. The extent to which the novel's consciousness of girlhood is accompanied by patriarchally-informed Shakespeare is clear in the following extended quotation in which Ella 'understands' her own needs:

When Ella got back from Lou's, she went up to her grandfather's room. She stood beside the bed, under the gaze of the stuffed parrot and the African statue, and thought about the two Pucks who had appeared so wondrously in her world. The two Pucks who transformed her from a dumbstruck Year Eight student into an ethereal fairy. They had swept her into a dream, but that dream was over. It had disappeared and they were disappearing with it. Nothing but a few weeks' bewitchment. Forming a theatre club was not going to bring it back-not without the two Pucks. ${ }^{31}$ 
21 My concern is not with these novels' romance plots per se. After all, it makes sense that as young people begin to know themselves as sexual beings, and sexuality begins to shape their peer relationships, narratives that address such issues are likely to be appealing to them, and can serve important social functions. My concern is with the repetition of implicating Shakespeare in heteronormative, patriarchy-friendly romance plots, and the near universally teleological approach to emplotting the romantic attention of a male (frequently a male who is desired by many other young women) as the culmination of adolescent, female selfhood. And, of course, the homogenous social location of the protagonists of Cupid Painted Blind, Faking Sweet, How to Keep a Boy from Kissing You, and In the Wings, being not only adolescent, Australian, and female; not only heterosexual, and feminine, but also economically privileged, white, well-educated, and living in mostly stable and safe domestic environments means that even as this subject position is linked with Shakespearean competency and personal success, it may well exclude alternative subjectivities from the same possibilities.

A variation on some of these themes is available in Lisa Shanahan's My Big Birkett. ${ }^{32}$ Protagonist Gemma Stone is playing Miranda in a school production of The Tempest, and in the course of auditions, rehearsals, and performance the Drama teacher and director of the production encourages Gemma to rewrite the play from Miranda's perspective in order to improve her performance as Miranda. ${ }^{33}$ Doing so enables Gemma to understand herself more fully as she makes explicit points of identification with and divergence from Shakespeare's Miranda.

When considering Miranda's instant attraction to Ferdinand, Gemma realises “I admired her and one part of me wanted to be like her too-but to think someone could love you so quickly, after only a day-it didn't make sense to me", ${ }^{34}$ and although she may herself be too emotionally closed-off, she also realises that mature emotional life is complicated. Later, as she watches Raven audition for Caliban, Gemma learns that it is not only the part on the page but the part as performed (understood internally) which shapes experience and identity (for the performer and potentially also the audience):

Everyone else had performed Caliban as if he were merely naughty. But Raven's Caliban was transparent with hunger. When he spoke, his skin was only a thin membrane around all the pulses drumming greedily in his body. I could see how he could haunt Miranda. As I watched, I felt scared. Scared like a little child who was staring at the bathwater swirling down the plughole-that swirling, grasping dark hole that gobbled and sucked whatever it was given and never full. ${ }^{35}$

In turn, playing Miranda initiates both self-critique and critique of the play: Gemma's Miranda rejects expectations (and Ferdinand) in favour of sympathy for and with Caliban. In her personal life, Gemma simultaneously learns not to assume that wealth or physical attractiveness guarantee goodness in other people and rejects the arrogant young man playing Prospero in favour of a friendship and eventually a romance with Raven. Raven's Calibanic status is socioeconomic as well as school-based: he comes from an impoverished, violent family whose criminal activities are well-known. However, attentive readers have already been cued to view him as 'more' than his Calibanic roots: Raven is a reader of Shakespeare prior to the school production as he has been set the task of learning Shakespearean soliloquies in detention, a narrative move which both identifies Raven as having an inclination for Shakespeare and the use of Shakespeare as a tool for social rehabilitation. ${ }^{36}$ 
gender, they nonetheless take seriously the proposition of girls as subjects. Tropes of education and subjectivity recur in these novels: Shakespeare is first (if not only) the province of formal schooling, although such encounters are most powerful when delivered through theatrical/performance encounters; the value of Shakespeare is to provide insight into character (both in the sense of identity and of morality), and to structure romantic relationships for girls. Intriguingly, it seems that where Shakespeare has been integrated into Australian culture, girlhood has become or remains an uncomfortable fit for that same culture. Or, to return to Driscoll's themes of girl studies: as these girl protagonists' culture gets "significant" (read: Shakespearean), their agency becomes problematic. people in real life, even though they may help. This is no less true of self-knowledge. When she is asked to "Write about Miranda's life from her perspective, in detail [and] Include scenes that don't take place in the play", ${ }^{37}$ Gemma crams "a whole notebook with Miranda's thoughts" ${ }^{38}$ until she achieves a kind of hybrid subjectivity: "Miranda's world filling my world so much, I was a citizen of two worlds". ${ }^{39}$ For herself and others, Shakespeare is a jumping-off point, or a prompt, rather than a template, a script, or an instruction manual. In several ways then, My Big Birkett offers a more complex vision than the novels discussed above. It still culminates in a romantic pairing, but the novel's romantic climax is an assertion of subjectivity on the part of Gemma who realises that "even though this life scares me, I still want to fly". ${ }^{40}$

practices of colonialism, but these novels are remarkably consistent both in their assertions that Shakespeare is useful and/or relevant for contemporary Australian adolescents and that it is to be inculcated as such through educational settings. This suggests a connection between the social and cultural reproductive functions of schooling. At the same time, the novels themselves potentially circulate within popular or non-schooling cultures for young readers; they comprise rather than critique the contemporary state of 'Australian Shakespeare', preferring to focus on the interpersonal relationships of their girl protagonists.

their agency becomes problematic.

\section{NOTES}

1. Henry Handel Richardson, Myself When Young, Melbourne, William Heinemann Ltd, 1948, p. 50-51.

2. Catherine Driscoll, "Girls Today: Girls, Girl Culture and Girl Studies”, Girlhood Studies vol. 1, no. 1, 2008, p. 13-32 (p. 25).

3. See Mark MacLeod, “Adapting and Parodying Shakespeare for Young Adults: John Marsden's Hamlet and Andy Griffiths' Just Macbeth!", in A. Mueller, ed., Adapting Canonical Texts in Children's Literature, London, Bloomsbury, 2013, p. 77-93 (p. 78-80). 
4. Richard Fotheringham \& Rob Pensalfini, "Anti-Colonial Voices? Non-British Accents and the National Authentication of Shakespeare in Australia in the 1970s", Australasian Drama Studies no. 50, 2007, 49-65 (p. 51).

5. Alan Brissenden, "Australian Shakespeare”, in G. Ioppolo, ed., Shakespeare Performed: Essays in Honor of R.A. Foakes, London, Associated University, 2000, p. 240-259 (p. 258).

6. Marnia Gonick, "Between 'Girl Power' and 'Reviving Ophelia': Constituting the Neoliberal Girl Subject”, NWSA Journal vol. 18, no. 2, 2006, 1-23 (p. 2).

7. Mary Pipher, Reviving Ophelia: Saving the Selves of Adolescent Girls, New York, Putnam, 1994.

8. Susan J. Wolfson, "Shakespeare and the Romantic Girl Reader", Nineteenth-Century Contexts vol. 21, no. 2, 1999, 191-234 (p. 219).

9. Gonick, op. cit., p. 19.

10. These novels can be read as part of a wider cultural pattern of such YA appropriations, but my focus here is on Australian YA romance novels with female protagonists. This means that I have excluded a number of Australian YA novels which appropriate Shakespeare: Jackie French's Macbeth and Son (Pymble, NSW, Angus \& Robertson, 2006), and several novels by Sophie Masson including The Tempestuous Voyage of Hopewell Shakespeare (London, Hodder, 2003), Malvolio's Revenge (London, Hodder, 2005), Cold Iron (Rydalmere, NSW, Hodder Headline, 1998), and The Understudy's Revenge (Gosford, NSW, Scholastic Press, 2011). Such novels are significant to understanding contemporary Australian literary engagement with Shakespeare, but by virtue of setting (e.g. historical, fantastic) or focus subjectivity (e.g. adolescent masculinity; nineteenthcentury British) fall beyond the scope of the current paper. For discussions of novels such as Ursula Dubosarsky's How to be a Great Detective (Camberwell, Vic., Puffin, 2004) and Penni Russon's Undine (Milsons Point, NSW, Random House, 2004) (excluded here due to length constraints), please see my 2009 book Shakespeare in Children's Literature: Gender and Cultural Capital (London, Routledge, 2009). More recently, I have discussed romance and feminism in Anglophone YA Hamlet texts in "Sink or Swim?: Revising Ophelia in Contemporary Young Adult Fiction," Children's Literature Association Quarterly vol. 38, no. 4, 2013, 435-448.

11. Hateley, op. cit., p. 15.

12. Charlotte Calder, Cupid Painted Blind, Sydney, Pan Macmillan, 2002.

13. Hateley, op. cit., p. 140-145.

14. Calder, op. cit., p. 31.

15. J. C. Burke, Faking Sweet, Sydney, Random House Australia, 2006.

16. Ibid., p. 58.

17. Ibid., p. 59.

18. One consequence of this approach is the reduction of Don John and Don Pedro's rivalries to schoolyard social relations: “'Actually I think Don John hates pretty much everyone. But the one he wants to get is Don Pedro.' 'Why? What did Don Pedro do?' 'Nothing, really, except that he's powerful and popular, I s'pose.' (Ibid., p. 121)

19. Ibid., p.135-139.

20. Ibid., p. 154.

21. Tara Eglington, How to Keep a Boy from Kissing You, Sydney, Angus \& Robertson, 2013.

22. Ibid., p. 15.

23. Ibid., p. 220.

24. I do not have the room to discuss here the ways in which How to Keep a Boy from Kissing You uses its one 'openly feminist' character, Sara, for comic relief.

25. Eglington, op. cit., p. 107.

26. Ibid., p. 312.

27. Ibid., p. 154.

28. Ibid., p. 145.

29. Elsbeth Edgar, In the Wings, Sydney, Walker Books, 2013. 
30. Ibid., p. 7.

31. Ibid., p. 247.

32. Lisa Shanahan, My Big Birkett, Crows Nest, NSW, Allen \& Unwin, 2006. Published in the US in 2007 as The Sweet, Terrible, Glorious Year I Truly, Completely Lost It.

33. The ubiquity of "writing from a character's perspective" school assignments is parodied in Barry Jonsberg's The Whole Business with Kiffo and the Pitbull (Crows Nest, NSW, Allen \& Unwin, 2004), when protagonist Calma wonders: "Do they somehow think that by setting a diary entry for homework they are somehow tapping into genuine adolescent interests?" (p. 77). More irritating to Calma than the unimaginative request that she write a diary entry from the perspective of Lady Macbeth is her teacher's disengaged assessment of the resulting assignment. Like My Big Birkett, Whole Business is also narrated by a girl who forms a relationship with a low socioeconomic status boy whose home life is marked by violence. Both novels culminate in young men's funerals, emphasising the real risks of violent environments. While I applaud the willingness of these texts to acknowledge the violence which shapes some young people's lives, I remain ambivalent about the ways in which a peer's death is deployed by Australian YA fiction to advance the protagonist's growth. Such 'necessary' deaths can be seen, for example, in Melina Marchetta's Looking for Alibrandi (Ringwood, Vic., Puffin, 1992) and Phillip Gwynne's Deadly, Unna? (Ringwood, Vic., Penguin, 1998).

34. Shanahan, op. cit., p. 132.

35. Ibid., p. 194.

36. Ibid., p. 152.

37. Ibid., p. 263.

38. Ibid., p. 265.

39. Ibid., p. 266.

40. Ibid., p. 333.

\section{ABSTRACTS}

This paper reads a selection of contemporary Australian young adult novels in order to consider their depiction of the meaning and significance of Shakespeare in the formation of young women's subjectivity. In the competing tensions of patriarchal and postcolonial social values, these novels suggest that Australian girls may take up Shakespeare in order to further their emotional development and interpersonal relationships, or they may take up Shakespeare as an academic ('professional') exercise. The careful delineations of personal and pedagogical uses for Shakespeare reflect wider cultural concerns about gender and culture in the Australian context.

Cet article étudie un éventail de romans australiens destinés aux jeunes adultes afin d'analyser ce que représente Shakespeare dans la formation de la subjectivité des jeunes femmes. Mettant en tension les valeurs sociales héritées d'une société patriarcale postcoloniale, ces romans suggèrent que les jeunes Australiennes se tournent vers Shakespeare dans leur développement émotionnel et leurs relations interpersonnelles, ou bien l'abordent dans le cadre d'exercices universitaires («professionnels»). La distinction entre utilisations personnelles et professionnelles de Shakespeare reflète des enjeux culturels plus larges, liés notamment au genre, au sein du contexte australien. 
INDEX

Mots-clés: adolescence, appropriation, éducation, genre, littérature de jeunesse, littérature postcoloniale, Shakespeare en Australie

Keywords: appropriation, gender, girlhood, postcolonial literature, schooling, Shakespeare in Australia, young adult literature

\section{AUTHOR}

\section{ERICA HATELEY}

Sør-Trøndelag University College 